\title{
PODSTAWY ODPOWIEDZIALNOŚCI MORALNEJ CHRZEŚCIJAN ZA MISJĘ EWEANGELIZACYJNĄ W ŚWIECIE
}

Misja ewangelizacyjna związana z głoszeniem Ewangelii jest najważniejszym powołaniem chrześcijańskim. Jest to służba dla bliźnich wypływająca z miłości. Jest to troska o bliźnich i o ich przyszłe zbawienie. Papież Franciszek w adhortacji Evangelii gaudium stwierdza to wyraźnie: „Ewangelizacja jest istotnie związana z głoszeniem Ewangelii 'tym, którzy nie znają Jezusa Chrystusa lub zawsze Go odrzucali'. Wielu z nich, ogarniętych tęsknotą za obliczem Boga, szuka Go w skrytości, również w krajach o starej tradycji chrześcijańskiej. Wszyscy mają prawo przyjąć Ewangelię. Chrześcijanie mają obowiązek głoszenia jej, nie wykluczając nikogo, nie jak ktoś, kto narzuca nowy obowiązek, ale jak ktoś, kto dzieli się radością, ukazuje piękną perspektywę, wydaje upragnioną ucztę"'. Doświadczenie Boga w Jezusie Chrystusie na trudnej drodze chrześcijańskiego życia apostolatu, sprawia, że chrześcijanin coraz bardziej upodabnia się do Chrystusa. Życie moralne istotnie posiada misyjny wymiar. Bez odniesienia do korzeni, do misyjnej natury Kościoła, a więc misyjnej natury każdego chrześcijanina, byłoby pozbawione istotnego pierwiastka. Życie moralne posiada wymiar misyjny, ponieważ myśleć, mówić i pracować dla misji, to widzieć i kochać człowieka.

\footnotetext{
${ }^{1}$ Fr a n c i s z e k, Adhortacja Evangelii gaudium, Rzym 2013, nr 14 (dalej: EG).
} 
Niniejsze studium służy analizie początków ewangelizacji. Przybliża więc najpierw osobę Jezusa Chrystusa, który sam rozpoczął głoszenie Słowa Bożego, dzieło ewangelizacji narodów. To wielkie dzieło Chrystusa jest pierwszym i najistotniejszym odniesieniem dla wspólnoty wierzących. Wylanie na uczniów Ducha Świętego dało z kolei początek ich apostolskiej działalności. Wychodząc więc od działalności Chrystusa, zostanie ukazana pierwsza wspólnota wierzących, ich zawierzenie Chrystusowi, ich poddanie tchnieniu Ducha Świętego i wreszcie ich działalność misyjna.

\section{JEZUS CHRYSTUS WZOREM GLOSICIELA EWA NGELII}

Podstawowym zadaniem Kościoła, jak twierdził papież Jan Paweł II w encyklice Redemptor hominis, jest skierowanie wzroku, świadomości i doświadczenia całej ludzkości w stronę tajemnicy Chrystusa $^{2}$. Został On posłany na świat jako prawdziwy pośrednik między Bogiem a ludźmi ${ }^{3}$. To z wiary w Chrystusa rodzi się powszechna misja Kościoła, co każdy wierny proklamuje w wyznaniu wiary ${ }^{4}$. „Kto wierzy w Syna Bożego, ten ma w sobie świadectwo Boga” (1 J 5, 10). ,Jest więc Kościół wspólnotą wyznawców Jezusa Chrystusa, którzy są adresatami nakazu swego Pana: «Idźcie na cały świat i głoście Ewangelię wszelkiemu stworzeniu» (Mk 16, 15)"’5. Kościół nie może uchylać się od tego nakazu, a tym samym nie może pozbawiać Dobrej Nowiny ludzi umiłowanych przez Boga, w Chrystusie

2 Por. J a n P aw eł II, Encyklika Redemptor hominis, Watykan 1979, nr 10 (dalej: RH).

${ }^{3}$ Por. Sobór Watykański II, Dekret o działalności misyjnej Kościoła Ad gentes divinitus, w: Sobór Watykański II, Konstytucje. Dekrety. Deklaracje, Poznań 1968, nr 3 (dalej: DMK).

4 Por. J a n P aw e 1 II, Encyklika Redemptoris missio, Watykan 1990, nr 4 (dalej: RM).

5 Por. EG 19. Por. także: D. Z i m o ń, Wprowadzenie do programu duszpasterskiego w roku 1994/95, w: Komisja Episkopatu Polski, Program duszpasterski na rok 1994/95, Katowice 1994, s. 9. 
bowiem ofiarowane jest każdemu człowiekowi zbawienie, jako dar łaski i miłosierdzia Bożego ${ }^{6}$.

Jezus Chrystus będąc początkiem i ośrodkiem Misji, jaką Bóg skierował do człowieka, stał się wypełnieniem Bożego zamysłu. Jego przykład jest jedną z głównych podstaw działalności misyjnej, gdyż został posłany, by ewangelizować, tak samo jak i Kościół, który kontynuuje Jego misję i czyni ją obecną ${ }^{7}$. Od początku swojej publicznej działalności Jezus staje się wzorem dla wszystkich misjonarzy ${ }^{8}$. W swych przypowieściach przedstawia Ojca jako Pana Żniwa, Właściciela Winnicy, który nieustannie wysyła swe sługi do pracy, a który ostatecznie wysyła swego własnego Syna'. Jezus głęboko doświadczał faktu tego posłania i stale powtarzał zdanie: „Ojciec, który mnie posłał”. Poprzez to posłannictwo Bóg wszed 1 w dzieje zbawienia w nowy sposób: „Bóg zaś dla ustalenia pokoju, czyli wspólnoty ze sobą, oraz dla ustalenia braterskiej społeczności wśród ludzi, będących grzesznikami, postanowił wkroczyć w historię ludzką w sposób nowy i ostateczny, posyłając Syna swego w naszym ciele, aby przez Niego uwolnić ludzi spod władzy ciemności i szatana i w Nim pojednać świat ze sobą"10. Jest więc w przypadku Jezusa sama osoba Boska posłana jako misjonarz.

Jezus rozpoczyna wypełniać plan Boży. Czytając Ewangelie zauważa się głęboką świadomość Jezusa, że Ojciec posłał Go dla wypełnienia szczególnej misji. Całe Jego życie należałoby widzieć jako wypełnianie tej misji ${ }^{11}$. Posłannictwo Jego zaczęło się przez tajemnicę Wcielenia i realizowało się w ten sam sposób, jednak publicznie znane

6 Por. RM 44.

7 Por. J. Ló p e z-G a y, Przepowiadanie, w: S. K a r o t e m p re 1 (red.), Kościół misyjny, Warszawa 1997, s. 104.

${ }^{8}$ Por. S. G ą d e c k i, Kościót jest misyjny, w: Komisja Episkopatu Polski, Program duszpasterski..., dz. cyt., s. 18.

9 Por. J. L o p e z- G a y, Trynitarny, chrystologiczny i pneumatologiczny wymiar misji, w: Elementy teologii misyjnej (br. red.), Pieniężno 1987, s. 69.

${ }^{10}$ DMK 3.

${ }^{11}$ Por. P. Va d a k u m p a d n, Eklezjologiczne podstawy misji, w: S. K a rot e m p r el (red.), Kościót misyjny..., dz. cyt., s. 89. 
stało się dopiero poprzez fakt chrztu w Jordanie ${ }^{12}$. Otrzymawszy Ducha Świętego, Jezus ujawnia swe powołanie mesjańskie chodząc po Galilei i głosząc Ewangelię Bożą: „Duch Pański spoczywa na Mnie, ponieważ Mnie namaścił i posłał Mnie, abym ubogim niósł dobrą nowinę, więźniom głosił wolność, a niewidomym przejrzenie" $(Ł k 4,18)$. Jest to również wskazanie na podstawowe prawo misyjne: konieczność Ducha Świętego w czasie urzeczywistniania misji.

Jezus ewangelizował naród izraelski, by - począwszy od niego zbawienie objęło cały świat ${ }^{13}$. „Tak Jezus obchodził wszystkie miasta i wioski. Nauczał w tamtejszych synagogach, głosił Ewangelię o Królestwie i leczył wszystkie choroby i wszystkie słabości” (Mt 9, 35). Królestwo ujawniało się więc w samej osobie Chrystusa, który przyszedł, ,żeby służyć i dać swoje życie jako okup za wielu” (Mk 10, $45)^{14}$. Przedmiotem Jego misji jest głoszenie i ustanowienie Królestwa Bożego, gdyż - jak sam mówi - na to został posłany. „Rzeczywistość eschatologiczna nie jest odłożona na odległe przyjście końca świata, ale staje się ona bliska i zaczyna się urzeczywistniać"15.

Rozpoczynając swoją działalność Jezus wyrusza w drogę. Wybierając uczniów ,przywołał do siebie tych, których sam chciał, a oni przyszli do Niego. I ustanowił Dwunastu, aby Mu towarzyszyli, by mógł wysłać ich na głoszenie nauki" (Mk 3, 13-14). O sobie Jezus mówi: „Duch Pański spoczywa na Mnie, ponieważ Mnie namaścił i posłał Mnie, abym ubogim niósł dobrą nowinę, więźniom głosił wolność, a niewidomym przejrzenie; abym uciśnionych odsyłał wolnymi, abym obwoływał rok łaski Pana" (Łk 4, 18-19). Podobnie nakazuje później czynić swoim uczniom (por. Mt 28, 18-20; Mk 16, 15-18; Łk 24, 46-49; J 20, 21-23). Wspólnym motywem ewangelicznych opisów posłania jest skierowanie uczniów do wszystkich narodów,

12 Por. J. L o p e z- G a y, Trynitarny, chrystologiczny i pneumatologiczny wymiar misji..., dz. cyt., s. 74 .

13 Por. J. M. G o i b u r u L o p e t e g u i, Duch misyjny. Vademecum, Warszawa 1991, s. 15.

14 Por. Sobór Watykański II, Konstytucja dogmatyczna o Kościele Lumen gentium, w: Sobór Watykański II, Konstytucje. Dekrety. Deklaracje..., dz. cyt., nr 5.

15 Tamże. 
na cały świat. Jezus posyłając daje również uczniom swoje wsparcie, poprzez obecność w Kościele Jego Ducha: „A oto Ja jestem z wami przez wszystkie dni, aż do skończenia świata" (Mt 28, 20).

Największym atutem Jezusa w Jego pracy misyjnej jest prawda ${ }^{16}$. Chrystus bowiem nie tylko głosił Królestwo, ale w Nim to Królestwo samo się uobecniło i wypełniło. „Zachodzi w Nim tożsamość pomiędzy posłaniem i posłanym, pomiędzy tym, co mówi, co czyni i czym jest. Jego moc, tajemnica skuteczności Jego działania, leży w całkowitym utożsamieniu ze zwiastowanym przez Niego orędziem" "17. Królestwo Boże nie jest programem do realizacji - jest przede wszystkim osobą, która ma imię Jezusa z Nazaretu, będącego obrazem Boga. Chrystus głosząc przypowieści, w których propaguje równość, obowiązek nawrócenia, miłość nieprzyjaciół, spędza swoje życie właśnie wśród ludzi prostych, biednych czy grzeszników. Ma świadomość konieczności posługiwania właśnie im. Równość i braterska miłość, wyrzeczenie i dzielenie się były wartościami, którymi żył Chrystus w sposób heroicznie doskonały, w swoim własnym ciele i krwi ${ }^{18}$. Jezus głosząc Dobrą Nowinę, daje więc pierwszeństwo tym, którzy znajdują się na marginesie społeczeństwa, aby podkreślić dostępność Królestwa dla wszystkich ludzi.

Chrystusowa ewangelizacja nie zamyka drogi do zbawienia nikomu, gdyż nie jest ono sprawą przynależności etnicznej, a dostępne jest poprzez wiarę. ,Jeżeli więc ustami swoimi wyznasz, że JEZUS JEST PANEM i w sercu swoim uwierzysz, że Bóg Go wskrzesił z martwych - osiągniesz zbawienie. Bo sercem przyjęta wiara prowadzi do sprawiedliwości, a wyznawanie jej ustami - do zbawienia" (Rz 10, 9-10). Jezus daje odczuć grzesznikom miłość Bożą poprzez swoją obecność. Nie gardzi nimi, a wręcz traktuje ich na równi, jak przyjaciół. Nikt nie jest bardziej opuszczony - w sensie

${ }^{16}$ Por. B e ne d y k t XVI, Encyklika Caritas in veritate, Tarnów 2009, nr 1 (dalej: CiV).

17 Tamże, nr 13.

18 Por. G. K o t t u p p a 11 i 1, Historia misji: wnioskiogólne, w: S. K a r o t e m p rel (red.), Kościót misyjny..., dz. cyt., s. 259. 
duchowym - jak nieznający prawdziwego Boga ${ }^{19}$. W najpiękniejszej i emocjonującej przypowieści, jaka wyszła z ust Jezusa - tej o synu marnotrawnym - główną intencją Chrystusa, według niektórych Ojców Kościoła, było jasne stwierdzenie, że poganie są powołani do uczestniczenia w uczcie rodziny Bożej z tych samych przyczyn, co Żydzi. Podobnie w przypowieści o zabłąkanej owcy Jezus mówi: „Tak samo w niebie większa będzie radość z jednego grzesznika, który się nawraca, niż z dziewięćdziesięciu dziewięciu sprawiedliwych, którzy nie potrzebują nawrócenia" (Łk 15, 7). Jezusa raduje też zachowanie i wiara setnika z Kafarnaum: „Zaprawdę, powiadam wam: U nikogo w Izraelu nie znalazłem tak wielkiej wiary" (Mt 8, 10).

Chrystus, jako jedyny pośrednik między Bogiem a człowiekiem, objawił się ludziom najpełniej poprzez Tajemnicę Odkupienia. „Kiedy raz na zawsze swoją śmiercią i zmartwychwstaniem dopełnił w sobie samym tajemnicę naszego zbawienia i odnowienia wszystkiego, osiągnąwszy jako Pan wszelką władzę w niebie i na ziemi, zanim został wzięty do nieba, założył swój Kościół jako sakrament zbawienia" ${ }^{20}$. Męka, śmierć, zmartwychwstanie i wniebowstąpienie Jezusa stały się szczytem przepowiadania Ewangeliii ${ }^{21}$. Święty Paweł w Pierwszym Liście do Tymoteusza stwierdza: „Albowiem jeden jest Bóg, jeden też pośrednik między Bogiem a ludźmi, człowiek, Chrystus Jezus, który wydał siebie samego na okup za wszystkich jako świadectwo, w oznaczonym czasie" (1 Tm 2, 5-6). Wszystkie akty w życiu Chrystusa, będąc Bożymi, posiadają nieskończoną wartość, mogą zbawić tysiące grzesznych światów. W tym celu wystarczyłaby jedna jedyna łza wylana w kolebce w Betlejem. Chrystus jednak w swoich niezgłębionych dla nas postanowieniach zechciał, aby krzyż był ceną zbawienia rodzaju ludzkiego, w ten sposób wszystkie inne działania Chrystusa pomagają nam w zbawieniu na tyle, na ile skierowane są na ofiarę krzyża ${ }^{22}$.

19 Por. J. M. Go ibur u L o p e t e g u i, Duch misyjny..., dz. cyt., s. 15.

20 DMK 5.

${ }^{21}$ Por. S. G ą d e c k i, Kościół jest misyjny..., dz. cyt., s. 19.

${ }^{22}$ Por. J. M. Goiburu Lo pet e gu i, Duch misyjny..., dz. cyt., s. 14. 
Chrystus stał się człowiekiem dla zbawienia wszystkich i poprzez to wydarzenie zjednoczył wszystkich. „Każdy bowiem jest ogarnięty Tajemnicą Odkupienia, z każdym Chrystus w tej tajemnicy raz na zawsze się zjednoczył"23. Święty Paweł pisze w Drugim Liście do Tymoteusza: „Weź udział w trudach i przeciwnościach znoszonych dla Ewangelii mocą Bożą! On nas wybawił i wezwał świętym powołaniem nie na podstawie naszych czynów, lecz stosownie do własnego postanowienia i łaski, która nam dana została w Chrystusie Jezusie przed wiecznymi czasami. Ukazana zaś została ona teraz przez pojawienie się naszego Zbawiciela, Chrystusa Jezusa, który zniweczył śmierć, a na życie i nieśmiertelność rzucił światło przez Ewangelię" (2 Tm 1, 8-10). Idąc więc myślą za św. Pawłem można stwierdzić, że jeśli Krzyż stale towarzyszy pracy misyjnej, jest to gwarancja, że Chrystus jest z nią ${ }^{24}$.

Kolejnym etapem misyjnej działalności Chrystusa jest czas po Jego zmartwychwstaniu. „Zmartwychwstanie nadaje zasięg uniwersalny orędziu Chrystusa, Jego działalności i całemu Jego posłannictwu. Uczniowie zdają sobie sprawę, że Królestwo jest już obecne w osobie Jezusa i budowane jest stopniowo w człowieku i świecie poprzez tajemniczą więź z Jego osobą"25. Jezus był najważniejszą przyczyną ewangelizacji. Poprzez to apostołowie zostali odważnymi świadkami i temu celowi ofiarowali swoje życie ${ }^{26}$. Ponadto nauczanie pierwotnego Kościoła skupia się właśnie na głoszeniu Jezusa Chrystusa, z którym Królestwo się utożsamia ${ }^{27}$. „Jeśli odrywa się Królestwo od Jezusa, nie ma już Królestwa Bożego przez Niego objawionego i dochodzi do wypaczenia zarówno sensu Królestwa, któremu zagraża przekształcenie się w cel czysto ludzki czy ideologiczny, jak i tożsamości Chrystusa, który nie jawi się już jako Pan,

${ }^{23}$ RH 13.

${ }^{24}$ Por. J. L o p e z - G a y, Trynitarny, chrystologiczny i pneumatologiczny wymiar misji..., dz. cyt., s. 77 .

25 RM 16.

${ }^{26}$ Por. G. K o t t u p p a 11 i 1, Historia misji: wnioski ogólne..., dz. cyt., s. 260.

27 Por. RM 16. 
któremu wszystko ma być poddane (por. 1 Kor 15, 27)"28. Podobne utożsamienie występuje pomiędzy Królestwem a Kościołem, ponieważ Jezus dał Ducha swojemu Kościołowi.

Kościół więc także musi wzrastać, a wzrost ten musi osiągnąć pełnię. Wszędzie tam, gdzie Duch Jezusa jest obecny, istnieje dynamizm w przepowiadaniu Słowa. ${ }^{29}$ Kościół jest bowiem na służbie Królestwa: przepowiadanie wzywające do nawrócenia jest podstawową służbą w celu urzeczywistniania Królestwa pojedynczym osobom i społecznościom ludzkim ${ }^{30}$. „Kościół winien kroczyć tą samą drogą pod działaniem Ducha Chrystusowego, jaką kroczył Chrystus, mianowicie drogą ubóstwa, posłuszeństwa, służby i ofiary z siebie aż do śmierci, z której przez zmartwychwstanie swoje powstał Chrystus zwycięzcą. Tak bowiem z nadzieją kroczyli wszyscy Apostołowie"31.

\section{ROLA DUCHA ŚWIECTEGO W POSLUDZE MISYJNEJ}

Po Zmartwychwstaniu Chrystus posyła swoich uczniów nie określając bezpośrednio kiedy ma nastąpić rozpoczęcie ich misyjnej działalności. Jedynie w Łukaszowej Ewangelii czytamy: „Oto Ja ześlę na was obietnicę mojego Ojca. Wy zaś pozostańcie w mieście, aż będziecie przyobleczeni w moc z wysoka" (Łk 24, 49). Mocą tą ma być Duch Święty, który uczyni misjonarzy z Apostołów ${ }^{32}$. Przekazując więc swe posłannictwo Jezus daje także swego Ducha. Dając misyjne przykazanie, daje również inny nakaz misyjny - oczekiwanie na zstąpienie Ducha Świętego. Tak też się dzieje. „U szczytu mesjańskiego posłannictwa Jezusa Duch Święty staje się obecny w pośrodku tajemnicy paschalnej w pełni swojej Boskiej podmiotowości: jako

28 Tamże, nr 18.

29 Por. B e n e d y k t XVI, Adhortacja apostolska Verbum Domini, Kraków 2010, nr 15-16 (dalej: VD).

${ }^{30}$ Por. RM 20.

${ }^{31}$ DMK 5.

32 Por. T. F e d e r i c i, Pneumatologiczne podstawy misji, w: S. K a r o t e m p r e 1 (red.), Kościół misyjny, dz. cyt., s. 73. 
Ten, który sam ma dalej prowadzić zbawcze dzieło, zakorzenione w ofierze Krzyża. Bez wątpienia dzieło to zostaje przez Jezusa zlecone ludziom: Apostołom, Kościołowi. Niemniej - w ludziach i poprzez ludzi - Duch Święty pozostaje pierwszym i nadrzędnym podmiotem jego urzeczywistniania w duszy człowieka i w dziejach świata" ${ }^{33}$. I tak jak od chwili zstąpienia Ducha Świętego na Najświętszą Maryję Pannę począł się Chrystus, a z chwilą zstąpienia na Niego w czasie modlitwy tegoż Ducha Świętego Chrystus wprowadzony został w swe dzieło, tak od dnia Zesłania Ducha Świętego zaczęła się misyjna działalność Apostołów ${ }^{34}$.

„W rzeczywistości dopiero po zstąpieniu Ducha Świętego w dzień Pięćdziesiątnicy Apostołowie idą na wszystkie strony świata, aby rozpocząć wielkie dzieło ewangelizacji powierzone Kościołowi”"35. W dniu Pięćdziesiątnicy bowiem „Duch zstąpił na grupę wahających się uczniów i przekształcił ich modlitwę, życie, apostolat i samozaparcie w męczeństwo. Taka duchowość zmieniła także ich sposób patrzenia na Boga, świat i siebie samych"36. Jest to dla Apostołów silne doświadczenie, które ich przemienia ${ }^{37}$. Wlewając $\mathrm{w}$ nich odwagę Duch Święty uzdalnia ich, by dawali świadectwo o Jezusie $\mathrm{z}$ otwartością ${ }^{38}$. A tenże Jezus pozostaje w Kościele dzięki mocy i wsparciu Ducha ${ }^{39}$.

Duch Święty nie jest posłany jako anonimowa siła, która ma na celu podtrzymywanie działalności misyjnej. Jest posłany jako Osoba

33 Sobór Watykański II, Konstytucja dogmatyczna o Objawianiu Bożym Dei Verbum, w: Sobór Watykański II, Konstytucje. Dekrety. Deklaracje..., dz. cyt., nr 42.

${ }^{34}$ Por. EG 21. Por. także: VD 15-16.

35 P a w e 1 VI, Adhortacja apostolska Evangelii nuntiandi, Watykan 1975, nr 75 (dalej: $\mathrm{EN}$ ).

${ }^{36}$ N. C o n t r a n, Duchowość misyjna, w: S. K a r o te m p rel (red.), Kościót misyjny..., dz. cyt., s. 150.

37 Por. RM 24.

38 Por. tamże.

39 Por. B e n e d y k t XVI, Encyklika Deus caritas est, Kraków 2006, nr 19. 
działająca ściśle w łączności i dialogu z Apostołami ${ }^{40}$. Pisze o tej współpracy św. Paweł w Liście do Efezjan: „bo przecież słyszeliście o udzieleniu przez Boga łaski danej mi dla was, że mianowicie przez objawienie oznajmiona mi została ta tajemnica" (Ef 3, 2-3). Z tego powodu powołanie misyjne przypisywane jest Duchowi Świętemu. Namaszczenie misjonarza przez Ducha Świętego ma na celu konsekrację misjonarza do wykonywania swego posłannictwa. Konsekracja ta jest także międzyosobowa: wychodzi od Ducha Świętego do misjonarza i konkretyzuje się we władzy wypełnienia posłannictwa ${ }^{41}$.

Zstąpienie Ducha Świętego było dla Apostołów niezwykłym wydarzeniem: „dał się słyszeć z nieba szum, jakby uderzenie gwałtownego wichru, i napełnił cały dom, w którym przebywali. Ukazały się im też jakby języki ognia, które się rozdzielały, i na każdym z nich spoczął jeden" (Dz 2, 2-3). Ogień w tradycji żydowskiej był wyjątkowym znakiem, gdyż w takiej postaci Bóg objawiał się swojemu ludowi: uczył, prowadził, zbawiał. „Znajomość tradycji żydowskiej pozwoliła też Apostołom zrozumieć, że «języki» oznaczały misję głoszenia, świadczenia i przepowiadania, którą powierzył im sam Jezus ${ }^{\text {"42 }}$. Duch Święty zaczyna więc działać ,jako Ten, który sam ma dalej prowadzić zbawcze dzieło, zakorzenione w ofierze Krzyża’ł3.

„Duch działa za pośrednictwem Apostołów, ale równocześnie

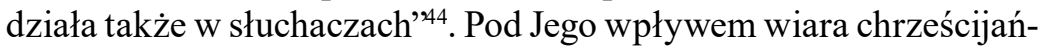
ska otwiera się na narody i świadectwo o Chrystusie rozszerza się ${ }^{45}$. „Kiedy Piotr jeszcze mówił o tym, Duch Święty zstąpił na wszystkich, którzy słuchali nauki. I zdumieli się wierni pochodzenia żydowskiego, którzy przybyli z Piotrem, że dar Ducha Świętego wylany został także na pogan” (Dz 10, 44-46). Motywacją dla apostołów jest

40 Por. J. L o p e z - G a y, Trynitarny, chrystologiczny i pneumatologiczny wymiar misji..., dz. cyt., s. 81 .

41 Por. tamże, s. 75.

${ }^{42}$ Por. J a n P a w eł II, Zamiast stowa wstępnego, w: Komisja Episkopatu Polski, Program duszpasterski..., dz. cyt., s. 5.

43 J a n P a w e ł II, Encyklika Dominum et vivificantem, Watykan 1986, nr 42.

44 RM 21.

45 Por. Tamże, nr 24. 
fakt, że Duch Święty wszystkim ofiaruje możliwość dojścia w sposób Bogu wiadomy do uczestnictwa w tej paschalnej tajemnicy ${ }^{46}$.

Jego obecność nie dotyczy tylko jednostek, ale narodów, kultur i religii, bowiem znajduje się On u źródła szlachetnych ideałów i inicjatyw ludzkości ${ }^{47}$. Duch Święty posyła Apostołów z misją do konkretnych wspólnot. Jest to nieco problematyczne, zwłaszcza w kontekście pogan. Pojawia się pytanie: „Czy jest dla nich wiążąca tradycja judaizmu i prawo obrzezania?" 48 Odpowiedź przychodzi również od Ducha Świętego: ,dla poganina nie jest konieczne poddanie się prawu, aby został chrześcijaninem"49. Dzieło Ducha Świętego rozbłyska więc w działalności misyjnej wśród narodów. Przyjmuje On jeszcze bardziej rolę przewodnika w wyborze osób i dróg dla misji. Misjonarze szli tą samą drogą, biorąc pod uwagę oczekiwania i nadzieje, niepokoje i cierpienia oraz kulturę ludzi, by głosić im zbawienie w Chrystusie. Wszędzie tam, gdzie Duch Jezusa jest obecny, istnieje dynamizm w przepowiadaniu Słowa ${ }^{50}$.

Poczynając od Chrystusa, poprzez Apostołów i Kościół, za sprawą Ducha Świętego może i musi rozszerzać się na cały świat proces powszechnego zjednoczenia w prawdzie oraz w miłości. Duch Święty jednoczy ludzi wzywając ich do Chrystusa poprzez wspólne działanie, głoszenie Ewangelii ${ }^{5}$. Ale Słowo nie tylko prowadzi do wiary. Poprzez tą wiarę, za jej przyczyną jednoczy z Duchem. „To Duch pobudza, by iść coraz dalej, nie tylko w sensie geograficznym, ale przekraczając bariery etniczne i religijne z misją prawdziwie powszechną"52. Duch Święty jest przecież tym, który pobudza i otwiera serca niechrześcijan, by słowo misjonarza dotarło do nich,

46 Por. Sobór Watykański II, Konstytucja duszpasterska o Kościele w świecie współczesnym Gaudium et spes, w: Sobór Watykański II, Konstytucje. Dekrety. Deklaracje..., dz. cyt., nr 22.

47 Por. RM 28.

48 Tamże, nr 24.

49 Tamże.

${ }^{50}$ Por. J. L ó p e z- G a y, Przepowiadanie..., dz. cyt., s. 105.

${ }^{51}$ Por. DMK 15.

52 RM 24. 
zostało przyjęte i przyniosło owoc zbawienia. Pisał papież Paweł VI w swojej encyklice Evangelii nuntiandi: „Duch Święty jest głównym sprawcą w szerzeniu Ewangelii, ponieważ On pobudza do przepowiadania i przygotowuje serce człowieka do przyjęcia i rozumienia słowa zbawienia"53.

Duch Święty pobudza grupę wierzących do tego, by stała się wspólnotą. Przygotowuje również przepowiadanie Kościoła poprzez udzielenie i rozwój darów łaski ${ }^{54}$. „Powszechnego działania Ducha nie należy też oddzielać od Jego specyficznego działania w ciele Chrystusa, którym jest Kościół"55. Duch Święty jak w początkach Kościoła, tak i dzisiaj działa w każdym głosicielu Ewangelii, podsuwa mu słowa. „Misja przeto nie opiera się na zdolnościach ludzkich, ale na mocy Zmartwychwstałego"56. Misjonarz wezwany jest do wiary w przemieniającą moc Ewangelii i do głoszenia tego, co Łukasz tak dobrze ukazuje w swej Ewangelii, mianowicie otwarcia się na miłość i miłosierdzie Boga. To Duch Święty przynagla do głoszenia wielkich dzieł Bożych: „Nie jest dla mnie powodem do chluby to, że głoszę Ewangelię. Świadom jestem ciążącego na mnie obowiązku. Biada mi, gdybym nie głosił Ewangelii!" (1Kor 9, 16). Jednak niezaprzeczalną prawdą jest, że ostatecznymi dokonawcami działalności misyjnej są Zmartwychwstały Chrystus i Duch Święty, którzy współpracują z chrześcijanami ${ }^{57}$. „Kościół winien kroczyć tą samą drogą pod działaniem Ducha Chrystusowego, jaką kroczył Chrystus, mianowicie drogą ubóstwa, posłuszeństwa, służby i ofiary z siebie aż do śmierci, z której przez zmartwychwstanie swoje powstał Chrystus zwycięzcą. Tak bowiem z nadzieją kroczyli wszyscy Apostołowie"58.

Widzimy więc, że Duch Święty także jest posłany i w Ojcu znajdujemy Jego posłannictwo. „Duch Święty, którego Ojciec pośle w moim

53 EN 75.

54 Por. T. F e d e r i c i, Pneumatologiczne podstawy misji..., dz. cyt., s. 73.

55 RM 29.

56 Tamże, nr 23.

57 Por. T. F e d e ri c i, Pneumatologiczne podstawy misji..., dz. cyt., s. 80.

58 DMK 5. 
imieniu" (J 14, 26) jest darem od Zmartwychwstałego Jezusa ${ }^{59}$. Jak w początkach Kościoła, tak i dzisiaj Duch Święty działa w każdym głosicielu Ewangelii, jeśli tylko poddaje się Jego kierownictwu. On podsuwa mu słowa, jakie tylko On jeden może poddać, a równocześnie usposabia serce słuchaczy, aby otwarli się na przyjęcie Ewangelii i na głoszone Królestwo.

\section{MISYJNY CHARAKTER KOŚCIOLA}

Owocem przepowiadania Jezusa Chrystusa było powstanie pierwszej wspólnoty wierzących. Przyjęli oni Chrystusa i Jego orędzie. Tak narodził się Kościół, który Jezus posłał, aby kontynuował Jego własną misję. Papież Paweł VI w swojej encyklice Evangelii nuntiandi pisał: „Kościół, zrodzony z tego rodzaju misji, z kolei sam został posłany przez Jezusa. Pan chwały wrócił do Ojca, a on zostaje na świecie. Jest jakby znakiem przyciemnionym, a zarazem jasnym nowej obecności Jezusa, Jego odejścia i pozostania. On nieprzerwanie je przedłuża"60.

Pierwotny Kościół wyraźnie pojmował siebie jako wspólnotę wezwaną do ewangelizacji. Misyjny nakaz Jezusa jest wyrazem głębokiego o tym przekonania. Wynikało to jednak nie tylko z nakazu, ale też z prawdziwego życia łaski w Kościele ${ }^{61}$. Dzieje Apostolskie opowiadają o początkach działalności misyjnej. W umysłach pierwszych chrześcijan przekonanie, że byli oni posłani, było bardzo silne. Dzieło zapoczątkowane przez samego Chrystusa miało być kontynuowane. Jedynie w tej dynamicznej perspektywie Kościół znajduje uzasadnienie dla siebie samego. Papież Paweł VI w encyklice Evangelii nuntiandi podkreślił, że „Kościół czuje się odpowiedzialny za zadanie rozprzestrzeniania Ewangelii"'62. Zadanie to powierzył bowiem Chrystus Apostołom, a tym samym całemu Kościołowi,

${ }_{59}$ Por. J. L o p e z- G a y, Trynitarny, chrystologiczny i pneumatologiczny wymiar misji..., dz. cyt., s. 79.

60 EN 15.

${ }^{61}$ Por. P. V a d a k u m p a d a n, Eklezjologiczne podstawy misji..., dz. cyt., s. 90.

62 EN 60. Por. także: VD 94. 
słowami: „Idźcie na cały świat i głoście Ewangelię wszelkiemu stworzeniu" (Mk 16, 15). Kościół winien zatem być misyjny, by w ten sposób zachowywać swoją tożsamośćc ${ }^{63}$. W misyjności swojej Kościół odnajduje korzenie i punkt wyjścia. Misyjność ta narzuca również Kościołowi jego charakter. Charakter bowiem jest to piętno, cecha wyróżniająca danej rzeczy lub osoby ${ }^{64}$. Kościół wyrasta, rodzi się ze swojej misyjności, wyrasta z ewangelizacji, którą sprawował sam Chrystus. Jest ukształtowany tą misyjnością i na niej wciąż się opiera.

Posłanie Kościoła do głoszenia Dobrej Nowiny było kontynuacją posłania Jezusa. Po wypełnieniu misji, którą zlecił Mu Ojciec Niebieski Jezus mówi do Apostołów: „Jak Ojciec Mnie posłał, tak i Ja was posyłam" (J 20, 21). Podkreślając ciągłość, jaka zaistniała pomiędzy Ojcem, Synem i Jego uczniami, Jezus mówi do Ojca: „Jak Ty Mnie posłałeś na świat, tak i Ja ich na świat posłałem" (J 17, 18). „Sami bowiem Apostołowie, na których Kościół został założony, idąc w ślady Chrystusa, "głosili słowo prawdy i rodzili Kościoły». A zadaniem ich następców jest nieustannie prowadzić to dzieło, aby «słowo Pańskie szerzyło się i rozsławiało» $(2$ Tes 3,1$)$ i aby Królestwo Boże na całym świecie głoszono i zakładano"65.

Apostołowie rozpoczęli więc swoje przepowiadanie bezpośrednio po otrzymaniu Ducha Świętego w dniu Pięćdziesiątnicy, zwanym często dniem narodzin Kościoła. Nowe życie, wlane przez Ducha, spontanicznie popchnęło ich do przekazywania go innym. Był to zarazem obowiązek, by Kościół w wypełnianiu swego posłannictwa posyłał głosicieli Ewangelii, aby przepowiadali Dobrą Nowinę o zbawieniu. Tak więc i teraz, w dzisiejszych czasach Kościół posyła swoich misjonarzy, jak niegdyś przełożeni Kościoła w Antiochii, po uprzednim poście i modlitwie, nałożyli swe ręce na Barnabę i Pawła i posłali ich jako misjonarzy, jak polecił Duch Święty (por Dz 13, 2-3).

${ }_{63}$ Por. P. V a d a k u m p a d a n, Eklezjologiczne podstawy misji..., dz. cyt., s. 85.

${ }^{64}$ Por. W. K o p a l i ń s k i, Słownik wyrazów obcych i zwrotów obcojęzycznych, Warszawa 1985, s. 73.

65 DMK 1. 
Jan Paweł II w encyklice Redemptoris missio uwypuklił, że Kościół jest pierwszym, który korzysta $\mathrm{z}$ dóbr zbawienia ${ }^{66}$. Wyjaśniają to słowa Dziejów Apostolskich, które mówią, że Chrystus ów Kościół nabył „własną krwią” (Dz 20, 28). Zachodzi więc między Chrystusem, Kościołem i ewangelizacją jak najściślejszy związek. Kościół posiada powierzony sobie urząd ewangelizowania. I nie godzi się korzystać z tego urzędu bez Kościoła, albo tym bardziej przeciw niemu. Ewangelizacja jest zawsze aktem eklezjalnym. Nie jest to czyjakolwiek czysto osobista inicjatywa. W porządku łaski i na płaszczyźnie instytucjonalnej każdy ewangelizujący i cała działalność ewangelizacyjna są związane z Kościołem powszechnym. Nie ma takiej działalności ewangelizacyjnej, która byłaby misją paralelną do misji Kościoła lub, co więcej, przeciwna Kościołowi ${ }^{67}$.

Chrystus pragnął, aby Kościół był sakramentem zbawienia dla wszystkich ludzi na ziemi. Powszechność zbawienia nie oznacza, że otrzymują je tylko ci, którzy w wyraźny sposób wierzą w Chrystusa i weszli do Kościoła. Jeśli zbawienie zostało przeznaczone dla wszystkich, musi ono być dane konkretnie do dyspozycji wszystkich. Kościół nie istnieje dla siebie samego, lecz dla prowadzenia ludzi do Jezusa Chrystusa. Nie może zatem zamykać się tylko na działania wewnętrzne. Jego wszelki wysiłek jest ukierunkowany na przepowiadanie i uobecnianie tajemnicy Jezusa Chrystusa. To z kolei wymaga otwarcia i zrozumienia, które pomagają Kościołowi w stawaniu się możliwie najdoskonalszym znakiem zbawienia pośród narodów. Zbawienie, które jest zawsze darem Ducha, pomimo swej dostępności, wymaga jednak współpracy człowieka. Tak zechciał Bóg i dlatego ustanowił Kościół i włączył go w plan zbawienia ${ }^{68}$. Nieustanna modlitwa Kościoła: ,przyjdź Królestwo Twoje”, zawiera w sobie jego cel oraz zadanie misji - budowanie Królestwa już tu, na ziemi.

Kościół może zachować swą tożsamość tylko w kontekście swojej misyjności. Wierność posłannictwu uzdalnia wspólnotę do wzrostu

\footnotetext{
66 Por. RM 9.

${ }^{67}$ Por. P. V a d a k u m p a d a n, Eklezjologiczne podstawy misji..., dz. cyt., s. 91.

68 Por. RM 9.
} 
jako Kościół Chrystusowy. Ewangelizacja jest pierwszorzędnym powołaniem i znakiem tożsamości Kościoła. Poza tą misją nie ma on celu sam w sobie. Wspólnota chrześcijańska ukazuje swoją własną tożsamość w sposób najbardziej widzialny, kiedy jest zgromadzona wokół stołu eucharystycznego. Tu umacnia się koinonia (braterstwo) i Kościół postępuje naprzód w głoszeniu Ewangelii z coraz większym oddaniem. Wspólnota, która celebruje Eucharystię, sama czuje się posłana. Aspekt wzajemnego dawania i otrzymywania jest tu wzmocniony. Eucharystia nieustannie buduje wspólnotę; ona to podsyca tę miłość, która jest duszą wszelkiej ewangelizacji.

W ciągu wieków Kościół wiernie głosił Ewangelię i świadczył o niej. Sam Jezus nie tylko dawał świadectwo prawdzie, lecz był Prawdą ${ }^{69}$. Wspólnota chrześcijańska nie będzie skutecznie przekazywała prawdy przez samo jej posiadanie lub głoszenie, lecz musi żyć prawdą i odnaleźć w niej swą tożsamość. W Kościele za pierwszy środek ewangelizowania należy uważać świadectwo życia prawdziwie chrześcijańskiego, które trwa w nierozłącznej wspólnocie z Bogiem, a zarazem w ożywieniu ducha otwartości i miłości poświęcania się dla innych ${ }^{70}$.

Dzieło zakładania Kościoła w określonej społeczności wtedy osiąga swój pewny kres, gdy zgromadzenie wiernych, zakorzenione już w życiu społecznym i w jakiejś mierze dostosowane do kultury miejscowej, cieszy się pewną trwałością i siłą, tzn. posiada własną, chociaż jeszcze niedostateczną liczbę rodzimych kapłanów, osób zakonnych i świeckich oraz wyposażone jest w urzędy i instytucje, które niezbędne są do prowadzenia i rozwoju życia Ludu Bożego pod kierownictwem własnego biskupa. „Kiedy młody Kościół, dzięki działalności misyjnej, zaczyna istnieć w określonym miejscu lub narodzie, wówczas jest on realizowaniem, aczkolwiek ograniczonym, Bożego planu względem wszystkich ludzi z danego miejsca. Ukazuje on tę komunię i nią żyje, jak chciał Ojciec i jak przywrócił ją Chrystus Odkupiciel: «Nie ma już Żyda ani poganina, nie ma już niewolnika

\footnotetext{
69 Por. CiV 1.

70 Por. DMK 6.
} 
ani człowieka wolnego, nie ma już mężczyzny ani kobiety, wszyscy bowiem jesteście kimś jednym w Chrystusie Jezusie» (Ga 3, 28)"'71.

Misyjny charakter jest więc piętnem, które Kościół nosi od swoich początków. Powszechna misja Kościoła rodzi się z nakazu Jezusa Chrystusa i urzeczywistnia w ciągu wieków przez głoszenie tajemnicy Boga Ojca, Syna i Ducha Świętego oraz tajemnicy wcielenia Syna jako wydarzenia niosącego zbawienie całej ludzkości. Uformowana przez Chrystusa wspólnota jest znakiem zjednoczenia, której oczekiwał Ojciec. Zjednoczenie to przywrócone zostało przez Syna w Duchu Świętym.

W ostatecznym Słowie swego Objawienia - w swoim Synu Jezusie Chrystusie, Bóg dał się poznać w sposób najpełniejszy: powiedział ludzkości kim jest. To ostateczne samoobjawienie się Boga jest podstawowym powodem, dla którego Kościół ,,jest misyjny ze swej natury”. Kościół nie może on nie głosić Ewangelii, gdyż jest ona pełnią prawdy, jaką Bóg dał nam poznać o samym sobie. Misja Chrystusa Odkupiciela, powierzona Kościołowi, nie została jeszcze bynajmniej wypełniona do końca. Gdy u schyłku drugiego tysiąclecia od Jego przyjścia obejmujemy spojrzeniem ludzkość, przekonujemy się, że misja Kościoła dopiero się rozpoczyna i że w jej służbie musimy zaangażować wszystkie nasze siły. Nie sposób bowiem oddzielić płaszczyzny życia Kościoła od ewangelizacji.

We współczesnym świecie zadaniem Kościoła jest wcielanie w czyn posłannictwa samego Chrystusa ${ }^{72}$. Głoszenie Ewangelii jest propozycją nowego życia, która nie narusza wolności człowieka. „W orędziu ewangelicznym Kościół daje siłę, która wyzwala i tworzy postęp właśnie dlatego, że prowadzi do nawrócenia serca i umysłu, do uznania godności każdej osoby, usposabia do solidarności, zaangażowania w posługę braciom, włącza człowieka w Boży plan, którym jest budowanie Królestwa pokoju i sprawiedliwości już w tym życiu"73.

${ }^{71}$ P. V a d a k u m p a d a n, Eklezjologiczne podstawy misji..., dz. cyt., s. 93.

72 Por. DMK 5.

73 RM 59. 
Rozważania powyższe służą analizie początków ewangelizacji. Chrystus zakładając swój Kościół posłał Apostołów, by głosili Ewangelię po wszystkie krańce ziemi. Nakaz ten, nie był dla Apostołów niczym zaskakującym, gdyż sam Chrystus wcześniej dał uczniom przykład owego głoszenia. Wspierani więc przez Ducha Świętego, którego otrzymali w dniu Pięćdziesiątnicy, idą i głoszą Ewangelię Chrystusową. W pierwotnym Kościele nie tylko Apostołowie byli posłani. Cała wspólnota czuła się odpowiedzialna za głoszenie Słowa Bożego. Był to jej obowiązek, a zarazem przywilej, jako tej, która Chrystusa znała, która przez Chrystusa została utworzona i uformowana.

Dokonane studium, wskazuje też na aktualność zagadnienia w odniesieniu do współczesnego Kościoła i każdego ucznia Chrystusa z osobna. Ponieważ zaś całe chrześcijańskie życie moralne realizowane jest $w$ dobie rosnących zmian na wielu płaszczyznach, zadaniem wiernych jest mocne angażowanie się do służby wszystkim braciom i siostrom, którzy nie poznali jeszcze Chrystusa, Jego miłości, a także tym, którzy zatracili swoją tożsamość pod wpływem współczesnej zeświecczonej kultury. Przypomina o tym papież Benedykt w adhortacji Verbum Domini: „U progu trzeciego tysiąclecia nie tylko istnieją liczne ludy, które jeszcze nie poznały Dobrej Nowiny, ale wielu chrześcijan potrzebuje, aby na nowo głoszono im z przekonaniem słowo Boże, by mogli konkretnie doświadczyć mocy Ewangelii. Tylu jest braci ochrzczonych, ale niewystarczająco ewangelizowanych. Często kraje niegdyś bogate w wiarę i powołania tracą swoją tożsamość pod wpływem kultury zeświecczonej" 74 .

Mimo wielu opracowań, które podejmują omawiane zagadnienie, kwestia misyjnego wymiaru moralnego życia chrześcijan, pozostaje tematem ciągle niewyczerpanym i otwartym. $Z$ kolei patrząc na dokonujące się w świecie przemiany, można zauważyć aktualność i potrzebę odnalezienia misyjnego wymiaru chrześcijańskiej moralności.

74 VD 96. 
Wielość wypowiedzi soborowych i papieskich pozwala ukazać różne aspekty ciągłej i naglącej potrzeby ewangelizacji współczesnego świata.

\section{Streszczenie}

Misja ewangelizacyjna związana z głoszeniem Ewangelii jest najważniejszym powołaniem chrześcijańskim. Jest świadectwem odpowiedzialności moralnej za tych, którzy nie poznali jeszcze Chrystusa. Doświadczenie Boga w Jezusie Chrystusie na trudnej drodze chrześcijańskiego życia apostolatu, sprawia, że chrześcijanin coraz bardziej upodabnia się do Chrystusa. Życie moralne posiada więc istotnie wymiar misyjny. Bez odniesienia do korzeni, do misyjnej natury każdego chrześcijanina, byłoby pozbawione istotnego pierwiastka.

Niniejsze studium służy analizie początków ewangelizacji. Przybliża więc najpierw osobę Jezusa Chrystusa, który sam rozpoczął głoszenie Słowa Bożego, dzieło ewangelizacji narodów. To wielkie dzieło Chrystusa jest pierwszym i najistotniejszym odniesieniem dla wspólnoty wierzących. Wylanie na uczniów Ducha Świętego dało z kolei początek ich apostolskiej działalności. Wychodząc więc od działalności Chrystusa, została ukazana pierwsza wspólnota wierzących, ich zawierzenie Chrystusowi, poddanie tchnieniu Ducha Świętego i wreszcie ich działalność misyjna.

\section{The fundamentals of Christians' moral responsibility for the evangelizing mission in the world Summary}

The evangelizing mission involving the proclamation of the Gospel is the most important Christian vocation. It is a testimony of the moral responsibility for those who do not know Christ yet. The experience of God in Jesus Christ on the difficult road of the Christian life of apostolate makes Christian become more like Christ. Therefore, the moral life has indeed a missionary dimension. Without reference to the roots, the missionary nature of every Christian, it would be deprived of the essential element.

The study is the analysis of the origins of evangelization. Thus, first of all it presents the person of Jesus Christ, who himself began preaching the Word of God, the work of evangelization of the nations. This great work of Christ is the first 
and the most important point of reference for the community of the faithful. The outpouring of the Holy Spirit upon the disciples gave the start to their apostolic activity. The first community of believers will be shown, starting from the activity of Christ, with their trust in Him, their submission to the Holy Spirit and finally their missionary activity.

Słowa klucze: misje, ewangelizacja, odpowiedzialność moralna, chrześcijanin, Jezus Chrystus, Duch Święty, Kościół.

Key words: missions, evangelization, moral responsibility, Christian, Jesus Christ, Holy Spirit, Church

Nota o autorze: ks. dr hab. Marek Kluz - Prodziekan Wydziału Teologicznego Sekcja w Tarnowie Uniwersytetu Papieskiego Jana Pawła II w Krakowie, Kierownik Podyplomowych Studiów z Etyki na WTST, adiunkt z habilitacją przy Katedrze Teologii Moralnej i Duchowości na WTST. Autor kilku książek i około 100 artykułów naukowych poświęconych moralności małżeńsko-rodzinnej, wychowaniu moralnemu, etyce cnót, moralności życia społecznego i działalności socjalno-charytatywnej.

\section{Bibliografia:}

Benedykt XVI, Adhortacja apostolska Verbum Domini, Kraków 2010.

Benedykt XVI, Encyklika Caritas in veritate, Tarnów 2009.

Benedykt XVI, Encyklika Deus caritas est, Kraków 2006.

Contran N., Duchowość misyjna, w: S. Karotemprel (red.), Kościót misyjny, Warszawa 1997, s. 150.

Federici T., Pneumatologiczne podstawy misji, w: S. Karotemprel (red.), Kościót misyjny, Warszawa 1997, s. 73.

Franciszek, Adhortacja Evangelii gaudium, Rzym 2013.

Gądecki S., Kościót jest misyjny, w: Komisja Episkopatu Polski, Program duszpasterski na rok 1994/95, Katowice 1994, s. 18.

Goiburu Lopetegui J. M., Duch misyjny. Vademecum, Warszawa 1991.

Jan Paweł II, Encyklika Dominum et vivificantem, Watykan 1986.

Jan Paweł II, Encyklika Redemptor hominis, Watykan 1979.

Jan Paweł II, Encyklika Redemptoris missio, Watykan 1990.

Jan Paweł II, Zamiast słowa wstepnego, w: Komisja Episkopatu Polski, Program duszpasterski na rok 1994/95, Katowice 1994, s. 5.

Kopaliński W., Słownik wyrazów obcych i zwrotów obcojęzycznych, Warszawa 1985. 
Kottuppallil G., Historia misji: wnioski ogólne, w: S. Karotemprel (red.), Kościót misyjny, Warszawa 1997 s. 259.

Lopez-Gay J., Trynitarny, chrystologiczny i pneumatologiczny wymiar misji, w: Elementy teologii misyjnej (br. red.), Pieniężno 1987, s. 69.

López-Gay J., Przepowiadanie, w: S. Karotemprel (red.), Kościót misyjny, Warszawa 1997, s. 104.

Paweł VI, Adhortacja apostolska Evangelii nuntiandi, Watykan 1975.

Sobór Watykański II, Konstytucje. Dekrety. Deklaracje, Poznań 1968.

Vadakumpadan P., Eklezjologiczne podstawy misji, w: S. Karotemprel (red.), Kościót misyjny, Warszawa 1997, s. 89.

Zimoń D., Wprowadzenie do programu duszpasterskiego w roku 1994/95, w: Komisja Episkopatu Polski, Program duszpasterski na rok 1994/95, Katowice 1994, s. 9. 